\title{
TEACHER EDUCATION IN ICT: CONTRIBUTIONS FROM DIFFERENT TRAINING MODELS
}

\section{La formación de docentes en TIC: aportaciones desde diferentes modelos de formación}

- Julio Cabero Almenara

Universidad de Sevilla, España

\cabero@us.es

(D) https://orcid.org/0000-0002-1133-6031
- Rubicelia Valencia Ortiz*

Instituto Latinoamericano de la Comunicación Educativa, México

\rubivalencia@gmail.com

(i) https://orcid.org/0000-0003-4656-5456

\begin{abstract}
Training the teaching staff in Information and Communication Technologies comes implicitly with the study of its different dimensions and principles, regarding the indications that have been pointed from a variety of studies and works. In our current society, it is clear that the significance of ICT to improve quality and educational performance is not exclusively determined by its presence, but also by the variety of transformations that involves not only using them as a way of consuming knowledge but also seeing them as tools to enrich, create and generate said knowledge. From this perspective, investment in professional development is more important than investment in resources associated with technology. This is an important aspect for incorporation of ITC, not considering only its use to do better things than we do without it, but to do things in a complete different manner. We present this article which describes a tour of some of the bases and models, analyzing the problematic of training in digital skills that teachers might face when they incorporate them into their teaching and professional practice.
\end{abstract}

Keywords: teacher education, vocational training, teacher education programs, technology education, the technology uses in education.

\section{Resumen}

Hablar de la formación del profesorado en Tecnologías de la Información y la Comunicación, implica el estudio de diferentes dimensiones y principios, contemplando las indicaciones que han apuntado distintos estudios y trabajos. En la sociedad actual, es claro que la significación de las TIC para mejorar la calidad y el rendimiento educativo, no viene exclusivamente determinado por su presencia, sino también por diferentes transformaciones que implican pasar de utilizarlas únicamente como una forma de consumir conocimientos, a verlas como herramientas para enriquecerlos, crearlos y generarlos. Desde esta perspectiva, la inversión en desarrollo profesional es más importante que la inversión en recursos asociados a la tecnología, siendo un aspecto importante para su incorporación, el no plantearse únicamente su utilización para hacer mejor las cosas que hacemos sin ellas, sino para hacer cosas completamente distintas. Desde esta óptica, planteamos el presente artículo en el que se describe un recorrido por algunas de las bases y modelos, analizando la problemática de la formación en las competencias digitales que debe poseer el profesorado a la hora de incorporarlas en su práctica docente y profesional.

Palabras clave: formación de docentes, formación profesional, tecnología educativa, tecnología educacional.

ISSN (impreso): 2636-2139

ISSN (en línea): 2636-2147

Sitio web: https://revistas.isfodosu.edu.do/recie
* Autor de correspondencia.

Recibido: 21 octubre 2018

Aprobado: 27 noviembre 2018

\section{COMO CITAR:}

Cabero-Almenara, J., \& Valencia-Ortiz, R. (2018). Teacher education in ICT: Contributions from different training models. Revista Caribeña de Investigación Educativa (RECIE), 2(2), 61-76. https://doi. org/10.32541/recie.2018.v2i2.pp61-76 


\section{The presence of ICT in teaching contexts}

One of the aspects that cannot be ignored in current training institutions is that they have been strongly influenced by the penetration of the "Information Communication Technologies" (ICT) in traditional and virtual classrooms. Never in the history of education has the teacher had so many opportunities to create environments enriched by technologies; and the teacher has never had so many possibilities to create individual and collaborative experiences with information, transforming traditional training scenarios in favor of different modes of interaction between the participants in the teaching-learning scenarios (Zempoalteca-Durán, Barragán-López, González \& Guzmán, 2017).

The penetration of ITC in education seems to be on the rise, with the presence of new emerging technologies (Tecnológico de Monterrey, 2015, Johnson \& Adams, 2016, Adams, Cummins, Davis, Freeman, Hall \& Ananthanarayanan, 2017) in the form of augmented and virtual reality, the internet, MOOCs, and learning analytics. In the same manner, theoretical and conceptual studies have been strengthened (Barroso \& Cabero, 2010, Escalona, Gómez \& Escalona, 2017).

Paradoxically, in the face of this strong presence and the many possibilities that ICTs allow, we find ourselves in a situation where "there has not been a direct correlation between better results, as for example in PISA reading tests, mathematics, and science, or in other national or international tests, as a result of investment in classroom technology." (Unesco, 2016, p. 16). Certain hopes that were put forth by some sectors predicted that the presence of ICT would transform education have not been confirmed. As Lichtman (2016) suggests, the deep and rich relationships between students, teachers, subject, and experience lead to more efficient learning transactions. However, many uses of ICT in education have served to greatly amplify the transference of knowledge but do little to take advantage of the relationships of the student, adult or child, with their peers, teachers or the relevance of what and why they are learning.

This may be due to a number of reasons, ranging from the assumption that the ICTs significance to improve quality and educational performance does not come exclusively by their sheer presence, but also by different factors, such as: a) changing the perceptions we have about their potential, and moving from perceiving them exclusively as ICT (Information and Communication Technologies) to observing them as TAC (Technologies for Learning and Knowledge) and as TEP (Technologies for Empowerment and Participation) (Cabero, 2014a; Pinto, Cortés \& Alfaro, 2017); b) fit technology into an innovation plan (Fundación Telefónica, 2016); or improve the professional and educational development of the teacher considering ICT. As indicated by Rossi and Barajas:

When the integration of ICT and innovative actions have been developed cooperatively or collaboratively on the basis of school projects, both the overcoming of difficulties and the motivation and involvement of teachers, have been reaffirmed, favoring the binomial digital teaching competence-pedagogical innovation (Rossi \& Barajas, 2018, p. 334).

As the "Inter-American Development Bank" points out, in order to improve learning, technological infrastructures are necessary, but not sufficient: 
"In order to achieve this goal, it is essential to work with the key actors of the learning process and coordinate their actions at the level of the education system. In the first place, teachers must be supported so that teaching responds more to the needs of the students, and they must be trained to teach in the new technological context" (Arias \& Cristia, 2014, p. 3).

In this respect, we faced with the following situations in this study. On the one hand, when teachers are asked about the attitudes, motivation, and degree of acceptance they have regarding ICT for their incorporation into teaching, the answers are usually positive (Teo, 2012; Guzmán, García \& Chaparro, 2011; Sang, Valcke, van Braak, Tondeur \& Zhu, 2011; Gutiérrez, 2014; Broadbent, 2016; Diep, Zhu, Struyven \& Blieck, 2017; González, 2017). But, on the other hand, the training they receive for the educational use of ICTs is low, and more so in regard to didactic aspects of technologies than to their instrumental management, a fact that seems to be a constant and is independent of the country in which the teacher exercises their profession (Cabero \& Barroso, 2016; Valdivieso \& Gonzáles, 2016; Sola, Nniya, Moreno \& Romero, 2017). Specifically, in the Spanish case according to the TALIS report (2009) and the "European Survey of Schools on ICT in Education" (2013), Spain is one of the countries in the European Union that has invested the most in training for teachers, and the surveys still point out that teachers perceive themselves as not being fully trained in educational use of ICTs.

There is no doubt that the training teachers have is crucial to use ICTs in their professional practice and to carry out more innovative uses of them (Vargas, Chumpitaz \& Suárez, 2014). The teacher of the future must possess a series of compentencies, such as: knowledge of how to collaborate and work as a team; ability to adapt easily to the changes and transformations of the new times and formative scenarios; capacity to assume the principle of "lifelong learning"; facility to give positive and meaningful value to their profession; and master ICT.

Unfortunately, regarding the proficient use of ICT, the situation cannot be very promising, as Fernández and Vázquez aptly describe:

Teacher training in the use of digital resources is inadequate. It is meaningless in the university, erratic at work, biased towards user computing to the detriment of digital pedagogical competence and without links to collaborative projects. The emphasis of resource producers is, therefore, shifting towards training and coaching (Fernández \& Vázquez, 2016, p.153).

This is a fact that arises to a certain extent because initial teacher training is quite disciplinary (Imbernón \& Colén, 2015).

However, from our point of view, it is not enough to determine the need for training but to reflect on how it should be addressed, from what educational models, and from what visions of teaching.

\section{Some models and perspectives for teacher training in ICT}

When discussing the training of teachers in ICT, one must not lose sight of what must be done from different dimensions and principles and contemplate at the same time the indications which 
have been pointed out through different studies and work, with respect to the process that teachers follow when incorporating them into their teaching and professional practice.

Regarding the first aspect, the proposals made by different authors (Cabero, 2014b; Cabero \& Marín, 2014; Tejada \& Pozos, 2018) lead us to highlight four principles when it comes to training teachers in ICT: 1) it is not enough to carry out training actions, but rather training should be done from different perspectives than they have been usually addressed and should not focus on purely technological approaches; 2) different dimensions must be taken into account: instrumental, semiologic/aesthetic, curricular, pragmatic, psychological, producer/designer, selection/evaluator, critic, organizer, attitudinal, and researcher at the time of their training; 3) in its implementation, a set of principles must be contemplated. The value of the practice and the reflection on it, considering in its application real problems for the teachers and not for the trainers or the technicians, the participation of the teaching staff in its construction and determination, its design as an unfinished product, focusing on the available media, placing itself within broader training strategies than mere audiovisual. Consequently, the planning should reach broader dimensions such as planning, design and evaluation, its development in natural teaching contexts, and the use of the deconstruction of messages mediated as principles for the learning of its realization and production; and 4) it must be a continuous process.

Talking about the training of teachers in ICT is to take into account, from the beginning, the policy of digital skills and the standards that have been published on them by different institutions and countries. In the first place, regarding its conceptualization, and according to the European Commission:

Digital competence involves the confident and critical use of Information Society Technology (IST) for work, leisure and communication. It is underpinned by basic skills in ICT: the use of computers to retrieve, assess, store, produce, present and exchange information, and to communicate and participate in collaborative networks via the Internet (European Parliament and the Council, 2006, p.15).

As noted, digital competence exceeds in extension and depth other concepts such as digital literacy and media, although these are part of the first.

A number of authors, considering the significance ICTs are acquiring in our society, have claimed that it is a key competence that teachers must possess, since their mastery and attitude towards ICTs will determine not only the use of technology but also their level and diversity of use (Cabero, Marín \& Llorente, 2012). Such is the importance of this competence that in the last Horizon Report (Adams, Cummins, Davis, Freeman, Hall \& Ananthanarayanan, 2017), it was reported that one of the challenges that must be overcome for the incorporation of ICT in training is the acquisition of this competence.

However, the problem lies in what aspects should, include such a digital competence (DC). Suárez, Almerich, Gargallo, and Aliaga (2013) differentiate in it two types of skills: technological and pedagogical. Prendes and Gutiérrez (2013), indicate that it is necessary to contemplate a diversity of them in function of the different actions that the teacher may have: teaching, research, and management. Cabero-Almenara, Marín, and Llorente (2012) say that from the perspective of the formation of the citizen in the DC indicate that this should focus on eight aspects: 1) Technological-resolutive, 2) 
Languages, 3) Ideological / political-axiological, 4) Digital identity, 5) Communication, 6) Aesthetics, 7) Economic and 8) Security-legislative. Rangel (2015), speaks of 13 competencies that revolve around three major dimensions: technological, informational and pedagogical. On the other hand, Valencia-Molina and Serna-Collazos (2016) when talking about ICT teacher training point out that they must work on competencies focused on the design, implementation, and evaluation of significant educational spaces mediated by ICT. To finalize the presentation of some proposals, we present the "National Institute of Educational Technologies and Teacher Training" of Spain (INTEF, 2017), which is the latest version of the "Common Framework of Digital Teacher Competence", contemplates five areas of basic competencies: 1) information and information literacy, 2) communication and collaboration, 3) creation of digital content, 4) the protection of personal information and data, protection of digital identity, security measures, responsible and safe use; and 5) Problem-solving.

Different standards for the training of teachers have been formulated around these proposals which have been widely treated in different studies such as Cabero, Marín and Llorente (2013) or the one of Cejas and Navío (2018). Here we present some focused on our Ibero-American context. The Ministry of Education of Chile through different years has made different proposals identifying the following digital competence that teachers must have: Pedagogical (competence to apply ICT in the current school curriculum as a way to support and expand learning and teaching); Technical (mastery of ICT for productivity (word processor, spreadsheet, presenter) and the Internet while having skills and new technologies that are emerging); Management (competence to support their work in the administrative area both at the personal and institutional level); Social, Ethical and Legal (knowing, appropriating and disseminating among their students the ethical, legal and social aspects related to the use of ICT and Internet); and Development and Professional Responsibility (being able to and access to various sources to improve their practices and facilitating the exchange of experiences that contribute through a process of reflection with various educational actors, to achieve better teaching and learning processes) (Ministry of Education of Chile, 2006). 16 specific standards are organized around these competencies.

The Ministry of National Education of Colombia (2013) has put forth a policy of training standards for teachers in ICT that are grouped around five major competences: technological, pedagogical, communicative, management, and research. For each one of these, a series of standards are established that are, in turn, divided into three groups: explorer, integrator and innovator; this suggesting processes of improvement and progress for the teacher in each of these digital competences.

For UNESCO (2008), the standards in digital ICT competences that teachers should have must be organized around the following major dimensions: politics and vision, curriculum and evaluation, pedagogy, ICT, diagnosis and administration, and professional training of the teacher. The European Commission (2017) has recently proposed a "Digital Competence Framework for Educators" (DigCompEdu), which is structured around the following proficiency levels:

- "Newcomers (A1): have had very little contact with digital tools and need guidance to expand their repertoire.

- Explorers (A2): have started using digital tools without, however, following a comprehensive or consistent approach. Explorers need insight and inspiration to expand their competences.

- Integrators (B1): use and experiment with digital tools for a range of purposes, trying to understand which digital strategies work best in which contexts. 
- Experts (B2): use a range of digital tools confidently, creatively and critically to enhance their professional activities. They continuously expand their repertoire of practices.

- Leaders (C1): rely on a broad repertoire of flexible, comprehensive and effective digital strategies. They are a source of inspiration for others.

- Pioneers (C2): question the adequacy of contemporary digital and pedagogical practices, of which they themselves are experts. They lead innovation and are a role model for younger teachers" (European Commission, 2017, p. 2).

This has led to the construction of a proposal for self-evaluation of the mastery of the digital competence of the teacher based on a series of variables that are presented in table 1.

Table 1:

DigCompEdu, Proficiency Progression by Area

\begin{tabular}{|c|c|c|c|c|c|}
\hline Levels & $\begin{array}{c}\text { A1 } \\
\text { Newcomer }\end{array}$ & $\begin{array}{c}\text { A2 } \\
\text { Explorer }\end{array}$ & $\begin{array}{c}\text { B1 } \\
\text { Integrator }\end{array}$ & $\begin{array}{c}\text { B2 } \\
\text { Expert }\end{array}$ & $\begin{array}{c}\text { C1 } \\
\text { Expert }\end{array}$ \\
\hline $\begin{array}{c}1 \\
\text { PROFESSIONAL } \\
\text { ENGAGEMENT }\end{array}$ & $\begin{array}{l}\text { AWARENESS; } \\
\text { UNCERTAINTY; } \\
\text { BASIC USE }\end{array}$ & $\begin{array}{l}\text { EXPLORING } \\
\text { DIGITAL } \\
\text { OPTIONS }\end{array}$ & $\begin{array}{l}\text { EXPANDING } \\
\text { PROFESSIONAL } \\
\text { PRACTICE }\end{array}$ & $\begin{array}{l}\text { ENHANCING } \\
\text { PROFESSIONAL } \\
\text { PRACTICE }\end{array}$ & $\begin{array}{l}\text { DISCUSSING AN } \\
\text { RENEWING } \\
\text { PROFESSIONAL } \\
\text { PRACTICE }\end{array}$ \\
\hline $\begin{array}{c}2 \\
\text { DIGITAL } \\
\text { RESOURCES }\end{array}$ & $\begin{array}{l}\text { AWARENESS; } \\
\text { UNCERTAINTY; } \\
\text { BASIC USE }\end{array}$ & $\begin{array}{l}\text { EXPLORING } \\
\text { DIGITAL } \\
\text { RESOURCES }\end{array}$ & $\begin{array}{l}\text { FITTING DIGITAL } \\
\text { RESOURCES TO } \\
\text { THE LEARNING } \\
\text { CONTEXT }\end{array}$ & $\begin{array}{l}\text { STRATEGICALLY } \\
\text { USING } \\
\text { INTERACTIVE } \\
\text { RESOURCES }\end{array}$ & $\begin{array}{l}\text { COMPREHENSIV } \\
\text { USING ADVANCE } \\
\text { STRATEGIES \& } \\
\text { RESOURCES }\end{array}$ \\
\hline $\begin{array}{c}3 \\
\text { TEACHING AND } \\
\text { LEARNING }\end{array}$ & $\begin{array}{l}\text { AWARENESS; } \\
\text { UNCERTAINTY; } \\
\text { BASIC USE }\end{array}$ & $\begin{array}{l}\text { EXPLORING } \\
\text { DIGITAL } \\
\text { TEACHING \& } \\
\text { LEARNING } \\
\text { STRATEGIES }\end{array}$ & $\begin{array}{l}\text { MEANINGFULLY } \\
\text { INTEGRATING } \\
\text { DIGITAL } \\
\text { TECHNOLOGIES }\end{array}$ & $\begin{array}{l}\text { ENHANCING } \\
\text { TEACHING \& } \\
\text { LEARNING } \\
\text { ACTIVITIES }\end{array}$ & $\begin{array}{l}\text { STRATEGICALLY } \\
\text { PURPOSEFULLY } \\
\text { RENEWING } \\
\text { TEACHING } \\
\text { PRACTICE }\end{array}$ \\
\hline $\begin{array}{c}4 \\
\text { ASSESSMENT }\end{array}$ & $\begin{array}{l}\text { AWARENESS; } \\
\text { UNCERTAINTY; } \\
\text { BASIC USE }\end{array}$ & $\begin{array}{l}\text { EXPLORING } \\
\text { DIGITAL } \\
\text { ASSESSMENT } \\
\text { STRATEGIES }\end{array}$ & $\begin{array}{l}\text { ENHANCING } \\
\text { TRADITIONAL } \\
\text { ASSESSMENT } \\
\text { APPROACHES }\end{array}$ & $\begin{array}{l}\text { STRATEGIC AND } \\
\text { EFFECTIVE USE } \\
\text { OF DIGITAL } \\
\text { ASSESSMENT }\end{array}$ & $\begin{array}{l}\text { CRITICALLY } \\
\text { REFLECTING ON } \\
\text { DIGITAL } \\
\text { ASSESSMENT } \\
\text { STRATEGIES }\end{array}$ \\
\hline $\begin{array}{c}\mathbf{5} \\
\text { EMPOWERING } \\
\text { LEARNERS }\end{array}$ & $\begin{array}{l}\text { AWARENESS; } \\
\text { UNCERTAINTY; } \\
\text { BASIC USE }\end{array}$ & $\begin{array}{l}\text { EXPLORING } \\
\text { LEARNER- } \\
\text { CENTRED } \\
\text { STRATEGIES }\end{array}$ & $\begin{array}{l}\text { ADDRESSING } \\
\text { LEARNER } \\
\text { EMPOWERMENT }\end{array}$ & $\begin{array}{l}\text { STRATEGICALLY } \\
\text { USING A RANGE } \\
\text { OF TOOLS TO } \\
\text { EMPOWER }\end{array}$ & $\begin{array}{l}\text { HOLISTICALLY } \\
\text { EMPOWERING } \\
\text { LEARNERS }\end{array}$ \\
\hline $\begin{array}{c}6 \\
\text { FACILITATING } \\
\text { LEARNERS' } \\
\text { DIGITAL } \\
\text { COMPETENCE }\end{array}$ & $\begin{array}{l}\text { AWARENESS; } \\
\text { UNCERTAINTY; } \\
\text { BASIC USE }\end{array}$ & $\begin{array}{l}\text { ENCOURAGING } \\
\text { LEARNERS TO } \\
\text { USE DIGITAL } \\
\text { TECHNOLOGIES }\end{array}$ & $\begin{array}{l}\text { IMPLEMENTING } \\
\text { ACTIVITIES TO } \\
\text { FOSTER } \\
\text { LEARNERS' } \\
\text { DIGITAL } \\
\text { COMPETENCE }\end{array}$ & $\begin{array}{l}\text { STRATEGICALLY } \\
\text { FOSTERING } \\
\text { LEARNERS' } \\
\text { DIGITAL } \\
\text { COMPETENCE }\end{array}$ & $\begin{array}{l}\text { COMPREHENSIVE } \\
\text { \& CRITICALLY } \\
\text { FOSTERING } \\
\text { LEARNERS' } \\
\text { DIGITAL } \\
\text { COMPETENCE }\end{array}$ \\
\hline
\end{tabular}

Source: Personal collection 
As Redecker and Punie point out (2017), DigCompEdu is a scientifically sound framework that helps guide policy and can be adapted directly to the implementation of regional and national training tools and programs. In addition, it provides a common language and approach that will encourage dialogue and the exchange of best practices across borders. The DigCompEdu framework is aimed at educators at all levels of education, from early childhood to higher education and education for adults, including general and vocational education and training, special education and non-formal learning contexts.

Beginning with the analysis of the models, one of the first proposals was elaborated by Hooper and Rieber (1995). For these authors, in the ICT adoption process, teachers go through different phases: familiarization (initial exposure time and familiarization with ICT, in which their management is learned outside the classroom context), use (in it learning is incorporated into classroom contexts), integration (the decision that certain tasks are carried out through ICT), reorientation (knowing the possibilities offered by ICT reconsiders and re-conceptualizes the teaching practice according to the characteristics of the student), and familiarization (it is perceived that there will never be a final solution with ICTs and one must be alert to the adoption of new decisions).

Krumsvik $(2009,2014)$, formulated a model to explain how the teacher reaches a high digital competence. It suggests that a teacher must pass through four stages. The first stage includes the acquisition of basic digital skills for access, management, evaluation, creation, and communication through ICT, or that which is considered digital literacy. Such training is acquired in the initial levels of teacher training, and it is becoming easier to acquire them taking into account the ease and simplicity of management that the technologies progressively have.

The second stage refers to the didactic competence that the teacher must possess in order to incorporate them into their educational practice, and this is marked by what Shulman (1987) called pedagogical knowledge and that Koehler and Mishra (2008) and that Mishra and Koehler (2006) extended to technological, pedagogical, and content or disciplinary knowledge. In this context, it is important that the teacher enhances a "mental literacy trip" (Krumsvk, 2009, p. 178) which takes him from being "digitally inconsistent and incompetent" to having a "high awareness and digital competence". This tour requires the support and guidance of their peers and additional training to increase their knowledge for the educational use of ICT. On the other hand, the teacher also carries out a "practical literacy itinerary" (Krumsvk, 2009, p. 179) in which he goes through a series of phases: adoption, adaptation, appropriation, and innovation. Krumsvk (2009, p. 179) points this out: "The main challenge for today's teachers is, first of all, the appropriation phase and the development of didactic competences on ICTs. This particular part of the didactic competence in ICT supposes that the teacher has the basic ICT skills as a premise to recognize the value of ICT."

The third level of this model includes learning strategies, through which the teacher is able to understand what the elements are, resources and sources to continue learning continuously, and to transfer this action to students, making sure they have the skills needed to continue learning through ICT and that they are aware of it. If the first phase is acquired in their initial teacher training, the others are achieved through their professional practice and in situations of educational immersion.

When the teacher reaches the last stage, construction or digital training, he has a critical, ethical and moral reflection on the role of ICT in human development, the social consequences of being in a society and a digital educational institution. It, therefore, means a reflective and critical view of ICT. 
A model that has acquired some importance in recent years is the "Technological Pedagogical Content Knowledge" (TPACK) developed by Mishra and Koehler (2006). Basically, the framework presented is that the training of teachers in ICT must go through the acquisition of three types of basic knowledge: technological (TK), pedagogical (PK), and content or disciplinary (CK), indicating through the model that the important thing is not to train teachers in this knowledge in isolation, but in combination: PCK: Pedagogical Content Knowledge; TCK: Technological Content Knowledge; TPK: Technological Pedagogical Knowledge; and TPACK: Technological, Pedagogical and Content Knowledge (Fig. 1). Although research carried out to validate it by means of structural equations has shown that some of the interactions between the different levels of "knowledge" are not well understood by teachers (Ay, Karadag \& Acat, 2015) and are difficult to establish, the reality is that a variety of studies and meta-analyses have been developed around this proposal (Chai, Koh \& Tsai, 2013; Ay, Karada \& Bahaddin, 2015; Cabero \& Barroso, 2016; Khine, Ali \& Afar, 2015; Navío and Barroso, 2016), which indicate its validity and significance for ICT teacher training, proposals that have also been diversified from studies of general use of ICT to specific technologies and specific disciplines (Smith, 2013; Tokmak, Incikabi \& Ozgelen, 2013; Hsu \& Liang, 2015; Deng, Sing, So, Qian \& Chen, 2017; Maor, 2017).

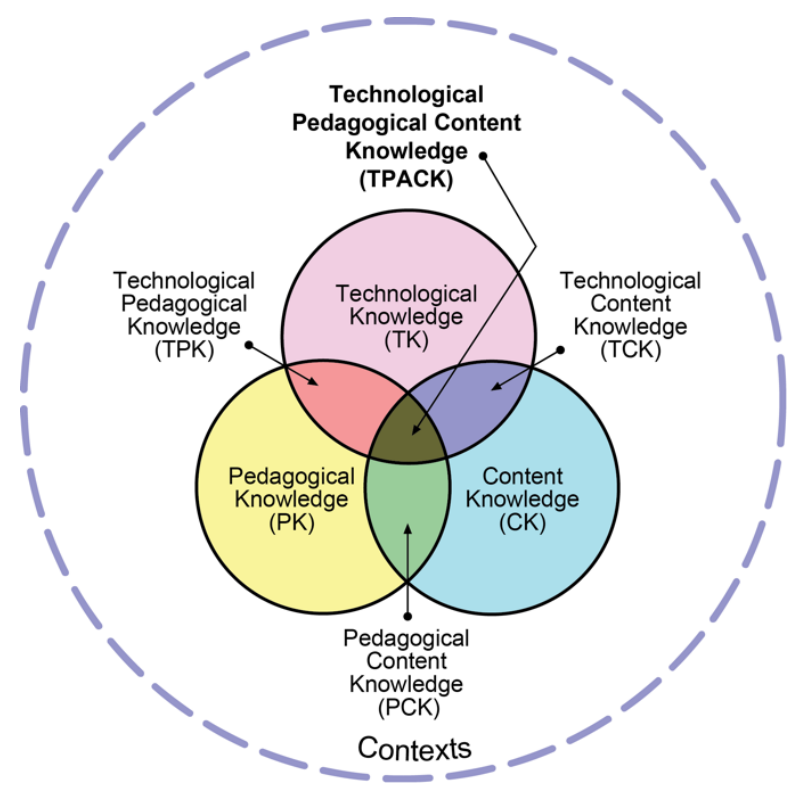

Figure 1. TPACK Framework (Mishra \& Koehler, 2006).

The structure of the TPACK framework has been significant when different supported training proposals have been made (Aguilar \& Barroso, 2018; Leiva, Ugalde \& Llorente, 2018), and therefore shows that for training to be meaningful it should pursue a transfer to the profession of the teacher (Cejas \& Navío, 2018).

Prendes and Gutiérrez (2013) propose a model that groups the ICT competencies that the teaching staff must possess in three basic areas: teaching, research, and management; indicating that each of them must pass through three progressive levels of mastery: "Domain Level 1. Competencies related to the knowledge bases that underlie the use of ICT. Domain Level 2. Includes the precise competencies to design, implement and evaluate actions with ICT, and Domain Level 3. It includes 
the competencies that are relevant for the teacher to reflectively and critically analyze the action carried out with ICT individually and to be able to carry out this analysis in collective contexts and to influence them" (Prendes \& Gutiérrez, 2013, p. 210).

Recently, another series of models has been appearing that seek to train teachers in digital skills that do not focus exclusively on training contexts, but rather amplify the use of ICTs to a social commitment; this is what has come to be called a holistic model, so that in addition to what is applied in the training contexts, it is able to use ICT to expand its relationship with the family and the student's environment, and make it sensitive to the use of ICT from a perspective of social commitment (Castañeda, Esteve \& Adell, 2018; Esteve, Castañeda \& Adell, 2018).

Regardless of the models, another way to establish principles for teacher training in ICT can be obtained from studies that have analyzed the process followed by the teacher in its use. In this sense, from the project ACOT (Apple Classrooms of Tomorrow), a project for which during a series of years the company Apple provided infrastructure and technological help to different centers of different North American states (Fisher, 1988, Dwyer, 1994, Salas-Castro \& Martínez, 2014) with the aim of knowing the processes that the teachers followed to adopt them. Conclusions that indicate that in the adoption of a technology they go through different phases (Figure 2), noting that teachers usually take three to five years to reach the innovation stage.

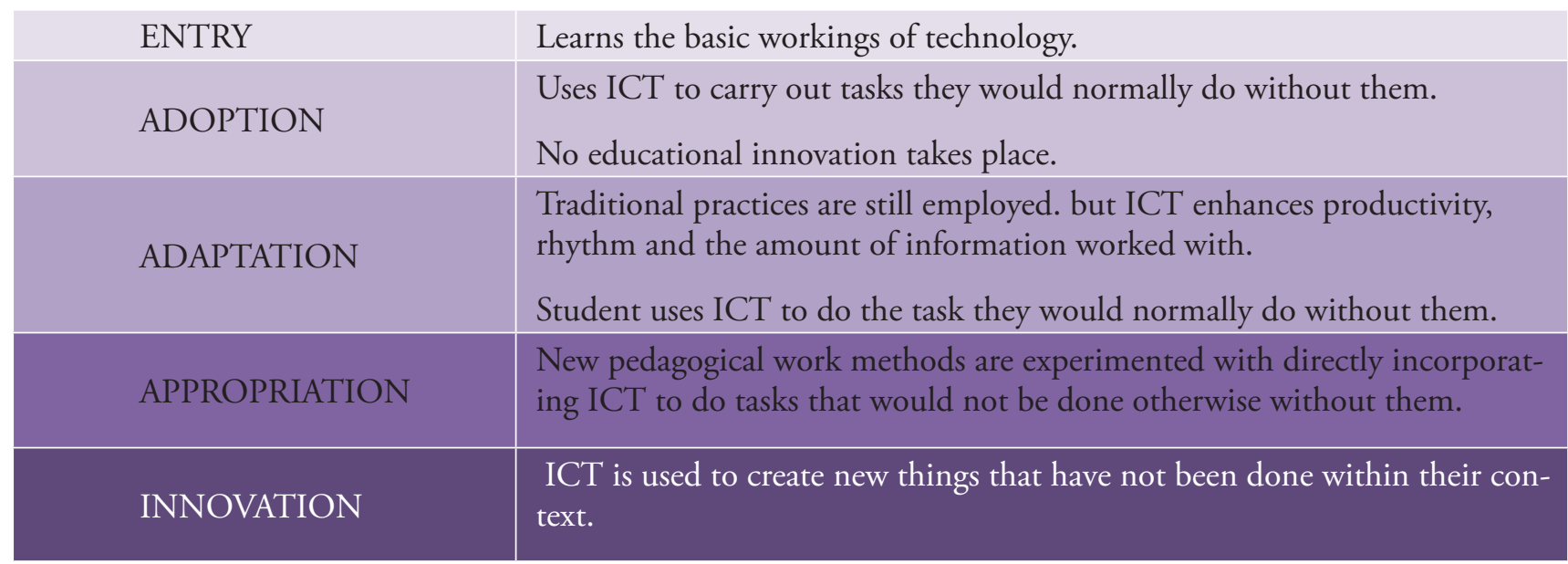

Figure 2. Phases of ICT adoption by teachers according to the ACOT project (1985). Source: Personal collection.

From the SAMR model (Substitution, Amplification, Modification and Redefinition) elaborated by Puentedura in 2014, but on which the limitation exists that the author himself has not made many publications, only writing on his personal blog (http://hippasus.com/blog), it is established that in the incorporation of ICT, the teacher goes through four stages: substitution, amplification, modification, and redefinition. While the first two involve the use of ICT for the improvement of the actions carried out by teachers, the last two suggest the transformation of the actions carried out through the application of ICT.

Likewise, García-Utrera, Figueroa-Rodríguez and Esquivel-Gámez (2014, pp. 207-208) explain the different stages in the following terms: 
- Substitution. It is the lowest level of use of ICT, and simply implies the substitution of one technology for another, without any methodological transformation. For example, change the transparencies for the overhead projector by the use of the power point.

- Increase. One ICT is replaced by another that incorporates functional improvements that facilitate the completion of tasks, no technological transformation. For example, the use of copy-paste in the word processor.

- Modification. It implies a methodological change in which the task to be carried out is redesigned by the introduction of technology. For example, the use of wikis, for students to reach a consensus on the definitions of terms.

- Redefinition. It implies the creation of new activities and learning environments that, without the use of available technology, would be impossible. For example, the use of augmented reality for the organization of artistic training itineraries for a city.

As Garcia-Utrera, Figueroa-Rodriguez and Esquivel-Gámez (2014, p. 216) have suggested, the model presents a series of limitations: a) it does not allow understanding of what influences teachers' decisions when they integrate technology; b) it constitutes a very linear scale of what really happens in teacher transformation when using technology; and c) its scale is limited because it does not consider other aspects such as the voluntary use of tools."

For us, this training process goes through three stages fundamentally: initiation-instrumentation, incorporation-substitution, and revision-transformation. The first one, involves contact with the technologies and their instrumental learning, usually carried out in the initial teacher training centers, although the ease and popularity of the technologies means that there is a deep learning through self-perfection; it must also acquire a vision of the "media galaxy" with which the teacher has for his professional practice and its adaptation to certain areas of knowledge and, at the same time, begin with the acquisition of conceptual bases regarding its use. In short, it is a phase of adopting an adequate level of literacy and digital aptitude, and understanding the role played by ICT in teaching-learning processes and in the development of the knowledge society, especially through those which the students acquire knowledge in non-formal and informal contexts.

The second would imply its incorporation into educational practice -initially to replace certain actions with technologies to make them more effective, efficient and attractive. It would also imply reflection on the behavior that ICTs acquire in real training contexts that will lead to a critical vision, neither apocalyptic nor integrated, regarding the possibilities of ICT in training processes. It is time to begin the transformation of digital literacy to digital competition. Its acquisition must be made through the practices of initial training, and immersion in educational centers with an experience in promoting the use of ICT to create new training scenarios.

The last phase involves the transformation of educational practice through the use of ICT. Assuming that it is not only a component that can be mobilized by the teacher, but that practices that favor the student becoming a "pro-consumer" of technological messages should be created. It is time to look for new ways of working with ICTs in function of the different disciplinary contents and to propose and investigate new forms of use. Its acquisition is carried out in the professional teaching action and can be enhanced through practice communities and collaborative work with other teachers. It is the moment in which the teacher acquires an aptitude and attitude regarding the application of ICT, and can become a "formator of trainers." 
In each of these stages, there will be a tendency towards training in different dimensions (design, educational use, management and administration, research, and ethics) which must be translated into specific standards and progressively becoming more complex as the teacher goes through the different stages of technical and conceptual appropriation of technology (Fig. 3).

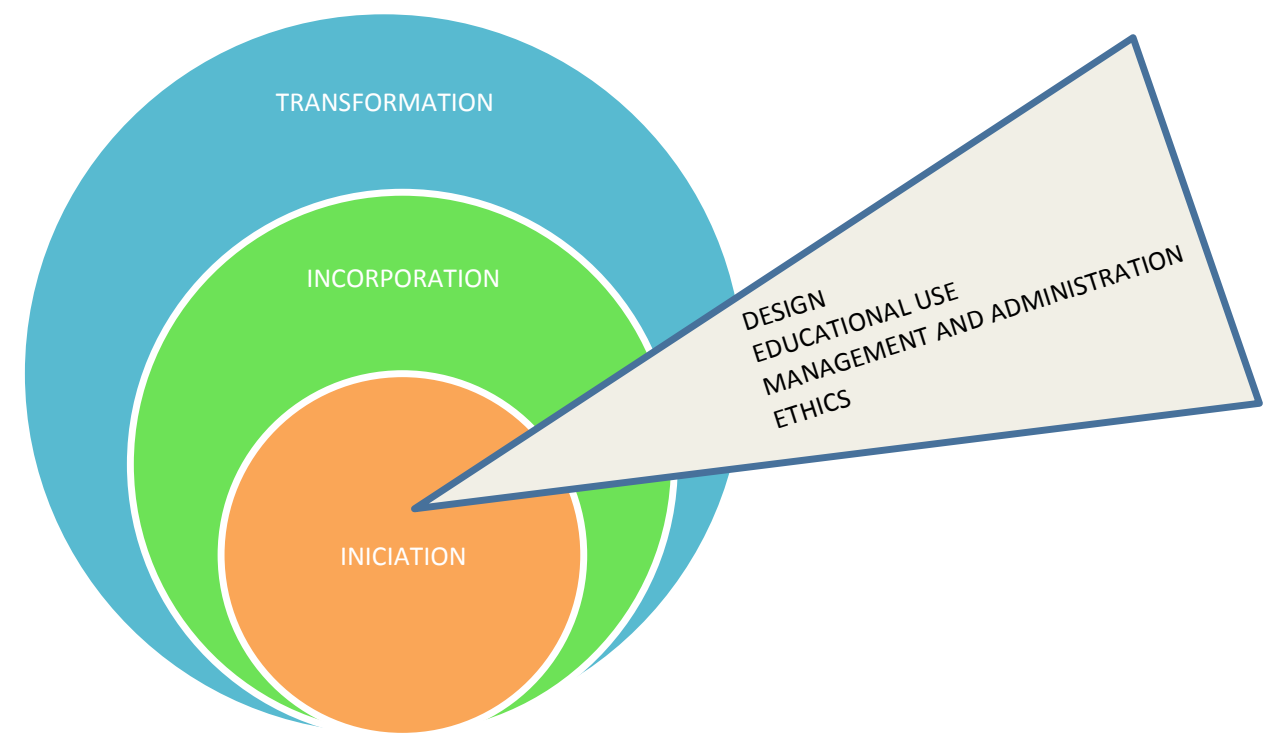

Figure 3. Phases and dimensions of teacher training in ICT. Source: Personal collection.

\section{Final Thoughts}

The foregoing allows one to attain a series of aspects to be considered in the training of ICT teachers. Their training must begin with an instrumental and technological training that only implies the beginning of their training. ICT training is gradual and takes time to reach its conceptual appropriation to make innovations and redefine the educational practice by creating new training environments and considering a teacher trained in ICT when he uses them, not only as a way to consume knowledge, but also to see them as tools to enrich, create and generate. Do not forget that the transformations of teaching do not come through ICT, but by the systemic perspective of the interaction of a series of elements: teachers, students, methodological, contextual and political.

To speak of teacher training in ICT is to talk about a theoretical-practical training. That does not fall into a mere instrumental training, with the lack of conceptual resources that have an impact on the teacher that does not have models for their incorporation into teaching and the transformation of educational practice.

In any case, one should not fall into the error of understanding the practice as a mere action to put into operation the acquired conceptually; the practice must necessarily, and even more in the case of ICT training, break the fascination that usually awakens, and involves action and reflection for its critical use. On the other hand, it must be recognized "practice as production and production of knowledge and does not (Marcondes, Finholdt \& Karl, 2017, p. 528).

At the same time, to speak of teacher training in ICT is to assume from the beginning that it is not a punctual action, but gradual. It must be taken from the knowledge and technical management 
of the instruments of the "media galaxy", to the transformation with of their educational practices to favor the creation of flexible environments and be enriched by them. And this, as we have been able to perceive in different models, is a progressive and transforming action.

\section{References}

Adams, S., Cummins, M., Davis, A., Freeman, A., Hall, C., \& Ananthanarayanan, V. (2017). NMC Horizon Report: 2017 Higher Education Edition. Austin, Texas: The New Media Consortium.

Aguilar, S., \& Barroso, J. (2018). Evaluación de un entorno de formación para la adquisición de competencias tecnológicas en el profesorado universitario. Profesorado. Revista de Curriculum y Formación de Profesorado, 22(3), 359-374. Retrieved from https://bit.ly/2Qhywcg

Arias, E., \& Cristia, J. (2014). El BID y la tecnología para mejorar el aprendizaje: ¡cómo promover programas efectivos. Banco Interamericano de Desarrollo. Washington DC.

Ay, Y., Karada, E., \& Acat, M. (2015). The Technological Pedagogical Content Knowledge practical (TPACKPractical) model: Examination of its validity in the Turkish culture via structural equation modeling. Computers \& Education, 88, 97-108. https://doi.org/10.1016/j.compedu.2015.04.017

Barroso, J., \& Cabero-Almenara, J. (2010). La investigación educativa en TIC. Visiones practices. Madrid: Síntesis.

Broadbent, J. (2016). Academic success is about self-efficacy rather than frequency of use of the learning management system. Australasian Journal of Educational Technology, 32(4), 38-49.

Cabero, J. (2014a). Nuevas miradas sobre las TIC aplicadas en la educación. Andalucía Educativa, 81. Retrived from http://bit.ly/2KcNF8g (3/03/2014).

Cabero, J. (2014b). Formación del profesorado universitario en TIC. Aplicación del método Delphi para la selección de los contenidos formativos. Educación XX1, 17(1), 111-132. http:// dx.doi.org/10.5944/educxx1.17.1.10707

Cabero, J., \& Barroso, J. (2016). ICT teacher training: a view of the TPACK model Cultura y Educación, 28(3), 633-663. http://dx.doi.org/10.1080/11356405.2016.1203526

Cabero, J., \& Marín, V. (2014). Miradas sobre la formación del profesorado en TIC. Enl@ce: Revista venezolana de Información, Tecnología y Conocimiento, 11(2), 11-24.

Cabero, J., Marín, V. \& Llorente, M.C (2012). Desarrollar la competencia digital docente. Sevilla: Eduforma.

Castañeda, L., Esteve, F., y Adell, J. (2018). ¿Por qué es necesario repensar la competencia docente para el mundo digital?. RED. Revista de Educación a Distancia. (56). http://dx.doi. org/10.6018/red/56/6

Cejas R., \& Navio, A. (2018). Formación en TIC del profesorado universitario. Factores que influyen en la transferencia a la función docente. Profesorado. Revista de Curriculum y formación del profesorado, 22(3), 271-293.

Cejas, R., Navío, A., \& Barroso, J. (2016). Las competencias del profesorado universitario desde el modelo TPACK (conocimiento tecnológico y pedagógico del contenido). Pixel-Bit. Revista de Medios y Educación, 49, 105-119. Recuperado de https://bit.ly/2L7zmTb

Chai, C. S., Koh, J. H. L., \& Tsai, C. C. (2013). A review of technological pedagogical content knowledge. Educational Technology \& Society, 16(2), 31-51 
Deng, F., Sing, Ch., So, H-J, Qian, Y., \& Chen, L. (2017). Examining the validity of the technological pedagogical content knowledge (TPACK) framework for preservice chemistry teachers. Australasian Journal of Educational Technology, 33(3), 1-14.

Diep, A., Zhu, Ch., Struyven, K., \& Blieck, Y. (2017). Who or what contributes to student satisfaction in different blended learning modalities? British Journal of Educational Technology, 48(2), 473-489. http://dx.doi.org/10.1111/bjet.12431

Dwyer, D. (1994). Apple Classrooms of Tomorrow: What We've Learned. Educational Leadership, 51(5), 4-10.

Escalona, J., Gómez, P., \& Escalona, I. (2017). Las TIC en la educación española a través de las publicaciones periódicas: un análisis bibliométrico. Pixel-Bit. Revista de Medios y Educación, 51, 21-36. Recuperado de https://bit.ly/2C4n4Ip

Esteve, F., Castañeda, L., \& Adell, J. (2018). Un Modelo Holístico de Competencia Docente para el Mundo Digital. Revista Interuniversitaria de Formación del Profesorado, 91(32.1), 105-116.

European Commission (2017). European Framework for the Digital Competence of Educators (DigCompEdu). Retrieved from http://bit.ly/2DtJtQk

European Commission (2013) Survey of schools: ICT in education. Final Report. Retrieved from http://bit.ly/2A2tTaZ

European Parliament and of the Council (2006). Recommendation of 18 December 2006, on key competences for lifelong learning, L394/10-L394/18. Retrieved from http://bit.ly/2TiOXD3

Fernández, M., \& Vázquez, S. (2016). La larga y compleja marcha del CLIP al CLIP. Escuela y profesorado en el nuevo entorno digital. Madrid: Fundación Telefónica-Ariel.

Fisher, Ch. (1988). The influence of High Computer Access on Schoolwork and Student Empowerment: An Exploratory Study of the Nashville ACOT Site. Apple Computer, Inc., Cupertino, CA.

Fundación Telefónica (2016). Prepara tu escuela para la sociedad digital. Madrid: Fundación Telefónica.

García-Utrera. L., Figueroa-Rodríguez, S., \& Esquivel-Gámez, I. (2014). Modelo de Sustitución, Aumento, Modificación, y Redefinición (SAMR): Fundamentos y aplicaciones. En I. Esquivel-Gámez (Coord.), Los Modelos Tecno-Educativos: Revolucionando el aprendizaje del siglo XXI (pp. 205-220). México: DSAE-Universidad Veracruzana.

González, N. (2017). Influencia del contexto en el desarrollo del conocimiento tecnológico pedagógico del contenido (TPACK) de un profesor universitario. Virtualidad, Educación y Ciencia, 8(14), 42-55.

Gutiérrez, I. (2014). Perfil del profesor universitario español en torno a las competencias en tecnologías de la información y la comunicación. Píxel-Bit. Revista de Medios y Educación. 44, 51-65.

Guzmán, T., García, M. T., \& Chaparro, N. (2011). Formación docente para la integración de las TIC en la práctica educativa. Apertura, 3(1). Retrieved from http://bit.ly/2KemgmC

Hooper, S., \& Rieber, L. P. (1995). Teaching with technology. In A. C. Ornstein (Ed.), Teaching: Theory into practice, (pp. 154-170). Needham Heights, MA: Allyn and Bacon.

Hsu, Ch., \& Liang, J. (2015). The Role of the TPACK in Game-Based Teaching: Does Instructional Sequence Matter? Asia-Pacific Educational Research, 24(3), 463-470. http://dx.doi. org/10.1007/s40299-014-0221-2

Imbernón, F., \& Colén, M.T. (2015). Los vaivenes de la formación inicial del profesorado. Una Reforma siempre inacabada. Tendencias Pedagógicas, 25, 57-76. 
Instituto Nacional de Tecnologías Educativas y de Formación del Profesorado (2017). Marco Común de Competencia Digital Docente. España: Ministerio de Educación Cultura y Deporte. Retrieved from http://bit.ly/2FtJy9j

Johnson, L., \& Adams, S., (2016). NMC Horizon Report: 2016 Higher Education Edition. Austin, Texas: The New Media Consortium.

Khine, M., Ali, N., \& Afar, E. (2015). Exploring relationships among TPACK constructs a n d ICT achievement among trainee teachers. Education Information Technology, 20, 241-263. http://dx.doi.org/10.1007/s10639-016-9507-8

Koehler, M.J., \& Mishra, P. (2008). Introducing TPCK. In AACTE Committee on Innovation and Technology (Ed.), The handbook of technological pedagogical content knowledge (TPCK) for educators (pp. 3-29). New York, NY: Routledge.

Krumsvik, R. J. (2009). Situated learning in the network society and the digitised school. European Journal of Teacher Education, 32(2), 167-185. https://doi.org/10.1080/02619760802457224

Krumsvik, R. J. (2014). Teacher educators' digital competence, Scandinavian Journal of Educational Research, 58(3), 269-280. http://dx.doi.org/10.1080/00313831.2012.726273

Leiva, J., Ugalde, L., \& Llorente, M.C. (2018). El modelo TPACK en la formación inicial de profesores: Modelo universidad de Playa Ancha (UPLA), Chile. Pixel-Bit. Revista de Medios y Educación, 53, 165-177.

Lichtman, G. (2016). Will educators get virtual reality right? ISTE. http://bit.ly/2FueeXQ

Maor, D. (2017). Using TPACK to develop digital pedagogues: a higher education experience. Journal Computer Education, 84(1), 71-86.

Marcondes, M.I., Finholdt, V., \& Karl, R. (2017). Integrating Theory and Practice in Initial Teacher Education, en Mena, J., García-Valcarcel, A., García Peñalvo, F.J. y Martín del Pozo, M. (Eds). Search and research: Teacher education for contemporary contexts (pp. 525-534), Salamanca: Ediciones Universidad.

Ministerio de Educación de Chile (2006). Estándares en Tecnología de la Información y la Comunicación para la Formación Inicial Docente. Santiago de Chile: Ministerio de Educación de Chile.

Ministerio de Educación Nacional de Colombia (2013). Competencias TIC. Para el desarrollo profesional docente. Bogotá: Ministerio de Educación Nacional.

Mishra, P., \& Koehler, M.J. (2006). Technological pedagogical content knowledge: A framework for teacher knowledge. The Teachers College Record, 108(6), 1017-1054.

Pinto, A., Cortés, O., \& Alfaro, C. (2017). Hacia la transformación de la práctica docente: modelo espiral de competencias TIC TAC TEP. Pixel-Bit. Revista de Medios y Educación, 51, 37-51. http://dx.doi.org/10.12795/pixelbit.2017.i51.03.

Prendes, M. P., \& Gutiérrez, I. (2013). Competencias tecnológicas del profesorado en las universidades espańolas. Revista de Educación, 361, 196-222. http://dx.doi.org/10.4438/1988-592XRE-2011-361-140

Puentedura, R. (2014). SAMR Model. Technology is Learning. Retrieved from http://bit.ly/2RYb9AI

Rangel, A. (2015). Competencias docentes digitales: propuesta de un perfil. Pixel-Bit. Revista de Medios y Educación, 46, 235-248. Recuperado de https://bit.ly/2A20xun

Redecker, Ch. \& Punie, Y. (2017). European Framework for the Digital Competence of Educators. Luxemburgo: Joint Research Centre. 
Rossi, A., \& Barajas, M. (2018). Competencia digital e innovación pedagógica: Desafíos y oportunidades. Revista de Curriculum y Formación de Profesorado, 22(3), 317-339.

Salas-Castro, R., \& Martínez, J. (2014). Aulas Apple del mañana: Resultados empíricos de educación básica (Modelo ACOT). En Esquivel-Gámez (Coord.), Los Modelos Tecno Educativos: Revolucionando el aprendizaje del siglo XXI (pp. 17-32). México: DSAE Universidad Veracruzana.

Sang, G., Valcke. M., van Braak, J., Tondeur, J., \& Zhu, Ch. (2011). Predicting ICT integration into classroom teaching in Chinese primary schools: exploring the complex interplay of teacher-related variables. Journal of Computer Assisted Learning, 27, 160-172.

Shulman, L.S. (1987). Knowledge and teaching: Foundations of the new reform. Harvard Educational Review, 57, 1-22.

Smith, S. (2013). Through the teacher's eyes: Unpacking the TPACK of digital fabrication integration in middle school language arts. Journal of Research on Technology in Education, 46(2), 207-227.

Sola, T., Nniya, M., Moreno, A., \& Romero, J.J. (2017). Valoración del profesorado de educación secundaria de la ciudad de Tetuán sobre la formación en TIC desarrollada desde el Ministerio de Educación Nacional. Pixel-Bit. Revista de Medios y Educación, 50, 49-63. Recuperado de https://bit.ly/2L7cmU4

Suárez, J., Almerich, G. Gargallo, B., \& Aliaga, F. (2013). Las competencias del profesorado en TIC: estructura básica. Educación XX1, 16(1), 39-62. http://dx.doi.org/10.5944/ educxx1.16.1.716

TALIS (2009). OCDE. Estudio Internacional sobre la Enseñanza y el Aprendizaje. Informe Español. Madrid: Secretaría de Estado de Educación y Formación Profesional.

Tecnológico de Monterrey (2015). Reporte EduTrends. Radar de Innovación Educativa 2015. Monterrey: Tecnológico de Monterrey.

Tejada, P., \& Pozos, K. (2018). Nuevos escenarios y competencias digitales docentes: hacia la profesionalización docente con TIC. Profesorado. Revista de Curriculum y Formación del Profesorado, $22(1), 25-51$.

Teo, T. (2012). Examining the intention to use technology among pre-service teachers: An integration of the technology acceptance model and theory of planned behavior. Interactive Learning Environments, 20(1), 3-18.

Tokmak, H., Incikabi, L., \& Ozgelen, S. (2013). An investigation of change in mathematics, science, and literacy education pre-service teachers' TPACK. Asian-Pacific Education Researcher, $22(4), 407-415$.

Unesco (2008). Estándares de competencias en TIC para docentes. Eduteka. Retrieved from http://bit. ly/2A2HVtm

UNESCO (2016). Tecnologías digitales al servicio de la calidad educativa. UNESCO: Santiago de Chile.

Valdivieso, T., \& Gonzáles, M.A. (2016). Competencia digital docente: ¿dónde estamos? Perfil del docente de educación primaria y secundaria. El caso de Ecuador. Pixel-Bit. Revista de Medios y Educación, 49, 57-73. http://dx.doi.org/10.12795/pixelbit.2016.i49.04

Valencia-Molina, T., \& Serna-Collazos, A. (2016). Competencias y estándares TIC desde la dimensión pedagógica: Una perspectiva desde los niveles de apropiación de las TIC en la práctica educativa docente. Cali: Pontificia Universidad Javeriana Cali - Unesco Oficina Santiago de Chile. 
Vargas, J., Chumpitaz, L., \& Suárez, G. (2014). Relación entre las competencias digitales de docentes de educación básica y el uso educativo de las tecnologías en las aulas. Revista de currículum y formación del profesorado, 18(3), 362-377.

Zempoalteca-Durán, B., Barragán-López, J., González, J., \& Guzmán, T (2017). Formación en TIC y competencia digital en la docencia en instituciones públicas de educación superior. Apertura, 9(1), 80-96. 